\title{
Use of Assessment of Satva sarata (Essence of Psyche) in Prognosis of Female Patient of Breast Cancer Receiving Chemotherapy
}

\begin{abstract}
Ayurveda adapt comprehensive psychosomatic approach to maintain health and cure disease. According to basic concept pravar satva sara person is able to bear any kind of mental stress, strain and pain. Cancer is one of the disease where needs psychosomatic approach of treatment to improve quality of life, specially breast cancer in females patients. Thus with an objective to know the importance of satvasarata in prognosis of female breast cancer female, in relation with blood indices, study was carried out. 60 patients selected according to selection criteria. Assessment Satva sara was done with proforma provided by MUHS, Nashik. Blood indices Hb, TLC, platelets, Blood urea, serum creatinine, SGOT and total bilirubin were observed for three consequently fallow up, on the basis of data obtained; pravar satva sarata female patients show good response to treatment with minimal changes in their blood indices.
\end{abstract}

Keywords: Ayurveda; Breast cancer; Satva sarata

\author{
Research Article \\ Volume 9 Issue 2 - 2017 \\ Kiran Tawalare ${ }^{1 *}$, Ganesh Hedaoo ${ }^{2}$, \\ Maneesha Kothekar ${ }^{1}$ and Kalpana Tawalare ${ }^{1}$ \\ ${ }^{1}$ Department of Kriya Sharir, Shri Ayurved College, India \\ ${ }^{2}$ Ayurved Physician, Kriya Sharir, India \\ *Corresponding author: Kiran Tawalare, Department of \\ Kriya Sharir, Shri Ayurved College, Hanuman Nagar, Nagpur \\ 440024, India, Tel: 9226209022; Email: \\ drkirantawalare@gmail.com \\ Received: August 30, 2017 | Published: November 09, 2017
}

\section{Introduction}

Ayurveda is science of life. It describe life as the complex combination of sharira (body), indriya (senses), satva (mind) and atma (soul) [1]. Anything that interferes with life can have an access to any one of these four and hence the treatment differs accordingly. Socially informal behaviors involve actions arising out of envy, pride, fear, anger, greed, attraction, self-righteous and delude thinking. All these activities arising out of raja and tama guna of mind and therefore included in pragyaparadh (intellectual error) [2]. Satva sara person not affected by the pragyaparadh as the person having psyche as a essence (satva sarata) are endowed with memory, devotion, grateful, learned, pure, courageous, skillful, resolute, free from anxiety, having well-directed and serious intellect and activities and engaged in virtuous acts [3] pragyaparadh can also minimized by sadvrutta (code of good conduct) and by retaining natural urges related to mind as kam (lust), krodh (anger), lobha (greedness), moha (attachment), irshya (jealous), mad (narcosis), shok (sorrow), chinta (worry), bhaya (fear) etc.

Classification of mental disorders based on exogenous and endogenous factors has been very systematically done in the ancient Ayurvedic manas dosh janya vyadhi. Endogenous factors are tridosha (vata, pitta, kapha) and triguna (satva, raja, tama). These disorders can be equated with neurotic disorders. It has been mentioned that occasionally manas roga (mental illnesses) may have contract with physical illnesses which may be equated to psycho-somatic disorders, and cure of some diseases also depends on psyche of the patient. Cancer is one of such a disease which hampered quality of life. Breast cancer among woman ranked second position in spreading.
Burden of cancer is alarmly increasing in economically developing countries like India, with respect to increasing population, aging and growth of country. In 2012, 1.7 million women globally diagnosed with breast cancer [4]. Breast cancer is the most frequently diagnosed cancer and the leading cause of cancer death among females, accounting for $23 \%$ of the total cancer cases and $14 \%$ of the cancer deaths [5]. Chemotherapy may be given with a curative intent or to reduce symptoms (palliative chemotherapy) so as to promote quality of life. Surgery, chemotherapy, and radiation therapy are very important step in the treatment of such tumor to increase the opportunity for breast conservation [6].

Modern application of drugs in the treatment of a person with cancer usually involves strong chemotherapeutic drugs used to attack the disorganized cancer cells and kill them. In this scenario, it is common for the patient to experience disabling side effects as fever, cough, hair loss, anorexia, fatigue, diarrhea, constipation, mouth ulceration, drowsiness, mood alteration etc which indicate some kind of harm to the normal functioning of body. In addition to this, surgical removal of breast adversely affects women beauty, this is also the major factor which disturb female mentally [7]. More support is needed towards the end of chemotherapy, when side effect comes aggressively some women should be referred for psychological support and Information [8]. Ayurveda requires rediscovery in light of our current knowledge of allopathic (modern) medicine for the therapeutic and preventive purpose [9].

Dhatusarata examination is one of tool used by ancient scientist. Among these ashtavidh dhatu sara examination of satva sarata is one, rasadhatu, raktadhatu, mansdhatu, meddhatu, 
ashtidhatu, majjadhatu and shukradhatu [10]. Satva sarata (essence of psyche) rules out the mental state of patient. With respect to vitality, satvasarata is of 3 types pravara (high), Madhya (moderate) and avara (low). In case of pravara-satva persons, no effect is seen on them due to diseases caused by vata, pitta and kapha. Madhya-satva persons have the attitude of good accommodation with other individuals. They can endure the diseases, due to their, medium pain bearing capacities. Hina satva persons can't control their urges. That means they have least capacities to bear the pain of disease [11]. Hence somewhere there is a relation between psyche condition and physical factors involved, which may equated to organic psychosis today. So with an objective to assess the use of satva sarata in prognosis of female breast cancer patient study was carried out.

\section{Aim}

To study use of satva sarata in assessing prognosis of female of breast cancer receiving chemotherapy in relation with blood indices.

\section{Material and Methods}

\section{Study design}

This is an observational descriptive study design conducted after obtaining necessary permission from the institutional ethical committee. For this study 60 female patients were selected randomly from hospital namely Rashtrasant Tukdoji Maharaj cancer government hospital, Nagpur.

\section{Inclusion Criteria}

Diagnosed female patients of breast cancer of age group 30 to 70 years receiving combined neo-adjuvant chemotherapy were enrolled for study.

\section{Exclusion Criteria}

a. The patient undergone for surgery of breast cancer was excluded.

b. The patient of distant metastasis excluded from study.

\section{Methods}

According to selection criteria diagnosed female patients of breast cancer were taken for the study. Satva sarata parikshan was carried out on the basis of proforma of dhatusarata examination provided by Maharashtra university of Health Sciences, Nashik. (Annexure I) Examination of satva sarata was done before starting neoadjuvant chemotherapy, along with laboratory investigation for hemoglobin, total leukocyte count, platelet count, blood urea, serum creatinine, SGOT, and total bilirubin. These lab investigations repeatedly have done after three successive chemotherapies. Total 14 attributes are available to assess satva sarata. (Annexure I) These 14 attributes considered as a $100 \%$. The obtained satva sarata was analyzed by following criteria.

Pravar sarata - scoring 65\% and above
Madhyam sarata - scoring $33.1 \%$ to $64.9 \%$

Avar sarata - scoring $33 \%$ and less

On the basis of score obtained, evaluation of pravar, madhyam and avar sarata was done.

\section{Observation and Result}

The statistical analysis was done by using SPSS 16.0 software. The comparison between avar satva sarata and pravar satva sara female in the form of quantitative data of different variables before first chemotherapy and after third chemotherapy was analysed by pair $t$ test of parametric distribution (Figures 1-7), (Table1).

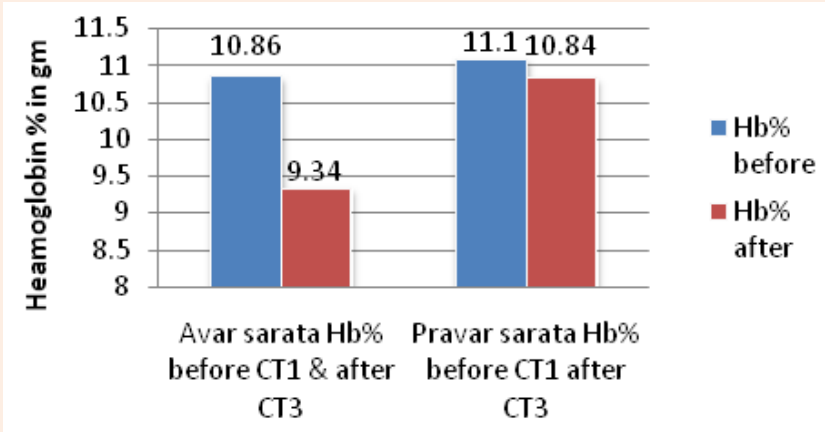

Figure 1: Showing before and after changes in hemoglobin $(\mathrm{Hb})$ in avar sarata \& pravar sarata.

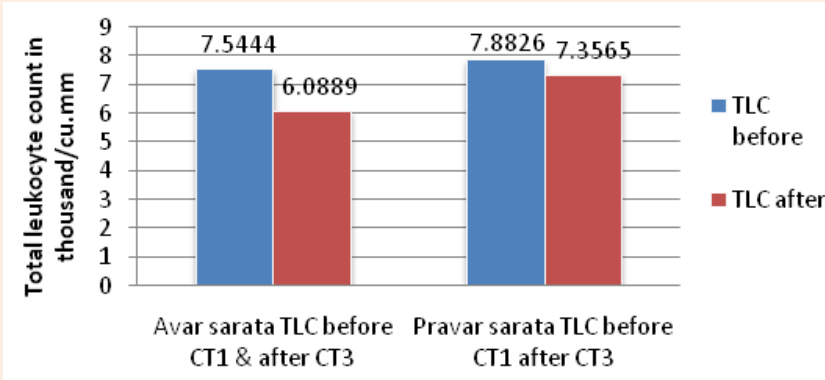

Figure 2: Showing before and after changes in Total leukocyte (TLC) in avar sarata \& pravar sarata.

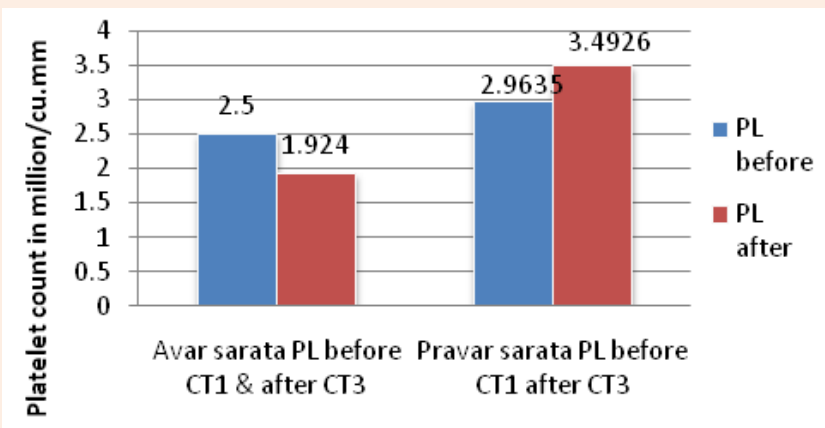

Figure 3: Showing before and after changes in Platelet (PL) in avar sarata \& pravar sarata. 
Table 1: The comparison between avar satva sarata and pravar satva sara female in the form of quantitative data of different variables before first chemotherapy.

\begin{tabular}{|c|c|c|c|c|c|}
\hline \multirow[b]{2}{*}{ Variables } & \multirow[b]{2}{*}{ Values } & \multicolumn{2}{|c|}{ Avar } & \multicolumn{2}{|c|}{ Pravar } \\
\hline & & Mean & SD & Mean & SD \\
\hline \multirow{3}{*}{ Hemoglobin (Hb) gm \% } & before CT1 $\mathrm{Hb}$ & 10.86 & 0.792 & 11.10 & 1.07 \\
\hline & after СТ3 $\mathrm{Hb}$ & 9.34 & 1.626 & 10.84 & 1.16 \\
\hline & $\mathrm{P}$ - value & $p-0.021 S$ & & $0.239 \mathrm{NS}$ & \\
\hline \multirow{3}{*}{$\begin{array}{l}\text { Total leukocyte count } \\
\text { (TLC)/cu.mm }\end{array}$} & before CT1 TLC & 7.5444 & 3718.5 & 7.8826 & 1995.5 \\
\hline & after CT3 TLC & 6.0889 & 2622.2 & 7.3565 & 1710.8 \\
\hline & $P$ - value & $p-0.075 S$ & & $0.251 \mathrm{NS}$ & \\
\hline \multirow{3}{*}{ Platelet (PL)/cu.mm } & before CT1 PL & 2.5000 & 59137.5 & 2.9635 & 1.0094 \\
\hline & after CT3 PL & 1.9240 & 1.3537 & 3.4926 & 1.6961 \\
\hline & $\mathrm{P}$ - value & $\mathrm{p}-0.804 \mathrm{NS}$ & & $0.031 \mathrm{~S}$ & \\
\hline \multirow{3}{*}{ Blood urea (BU) mg/dl } & before CT1 BU & 29.85 & 14.31 & 22.98 & 7.27 \\
\hline & after CT3 BU & 25.76 & 12.07 & 21.08 & 10.95 \\
\hline & $\mathrm{P}$ - value & $p-0.320 \mathrm{NS}$ & & $0.378 \mathrm{NS}$ & \\
\hline \multirow{3}{*}{$\begin{array}{l}\text { Serum creatinine (SC) } \\
\mathrm{mg} / \mathrm{dl}\end{array}$} & before CT1 SC & 0.9711 & 0.2225 & 0.9465 & 0.2399 \\
\hline & after CT3 SC & 1.047 & 0.3338 & 0.8943 & 0.3087 \\
\hline & $\mathrm{P}$ - value & $p-0.503 \mathrm{NS}$ & & $0.253 \mathrm{NS}$ & \\
\hline \multirow{3}{*}{ SGOT U/L } & before CT1 SGOT & 44.55 & 46.67 & 30.56 & 10.63 \\
\hline & after CT3 SGOT & 30.54 & 11.61 & 29.99 & 8.86 \\
\hline & $\mathrm{P}$ - value & $\mathrm{p}-0.340 \mathrm{NS}$ & & $0.872 \mathrm{NS}$ & \\
\hline \multirow{3}{*}{ Total bilirubin (TB) mg/dl } & before CT1 TB & 0.4944 & 0.1810 & 0.4139 & 0.1174 \\
\hline & after CT3 TB & 0.4667 & 0.3310 & 0.4065 & 0.1267 \\
\hline & $P$ - value & $\mathrm{p}-0.809 \mathrm{NS}$ & & $0.770 \mathrm{NS}$ & \\
\hline
\end{tabular}

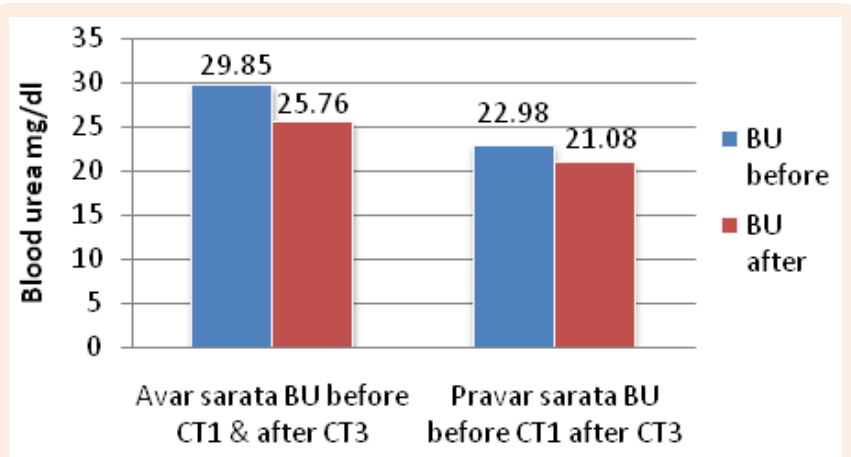

Figure 4: Showing before and after changes in Blood urea (BU) in avar sarata \& pravar sarata

\section{Discussion}

The examination of emotional factors (manasika bhavas) and the importance of mental characteristics for determining the prognosis of the diseases have been brightly described in Ayurveda [12]. The importance of examination of satva is stressed as the determination of psychic personality (manas prakriti) is essential to the treatment of the patient [13]. According to physiology of sapta dhatu health is depend upon rakta dhatu (blood) [14]. Therefore it was taken under consideration. Classification of tissues described in Ayurveda is based on some rational observations. The dhatu production and formation depends upon 'Jathaaagni' and 'dhatvagni' also. If these fractions become over active, there will be lead to 'Ksaya' (Catabolism) of 'dhatu' and if they become depressed, there will be abnormal 'Vrddhi' of 'dhatu'. Suggesting that in case of avar dhatu sarata people, dhatvagni is abnormal condition which may be due to nonstandard factors like dietary habits, living styles and psychological status.

This might be due to possessing special characteristics of pravar dhatusarata, person of pravar dhatusara have all the essence of dhatu. They are strong and happy in all the conditions, they are enduring confidant in all actions, they are inclined to caring acts, they are capable to express happiness in trouble condition as well, and having good relation with society boost their mind to get rid from fear of disease make them good response to treatment. However, it is very difficult to explain the association between psychological effects using blood investigation by exploratory 
study. For this further research with more sample size could be done [15]. Hence in pravar satva sarata person $\mathrm{Hb}, \mathrm{TLC}, \mathrm{Pl}$ and SC not declined up to level, as in case of avar satva sara. The following factors also influence the promotion of immunity like place of birth, time of birth, favorable weather, excellence of genetic qualities, excellence of properties of food being consumed, excellence of physique, good ability to tolerate various factors, excellence of mental status, favorable factors related to nature, youthfulness, exercise and cheerful attitude Such qualities are deficient in avar satva sarata therefore may shows poor response.

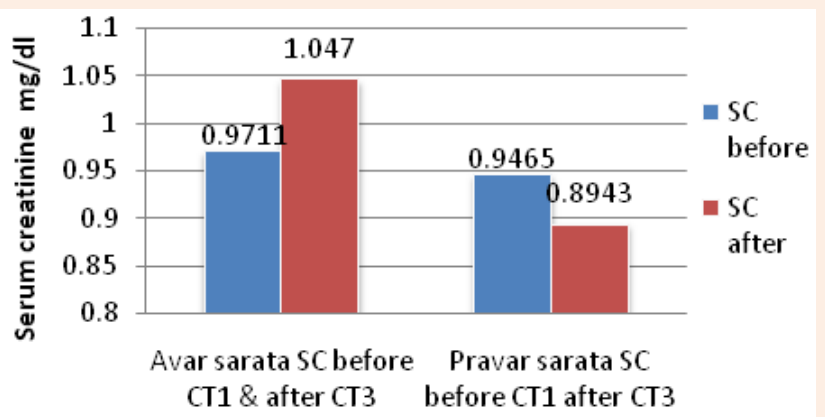

Figure 5: Showing before and after changes in Serum creatinine (SC) in avar sarata \& pravar sarata

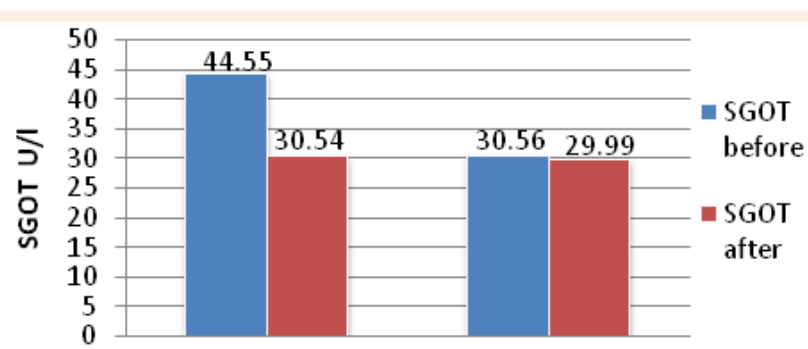

Avar sarata SGOT Pravar sarata SGOT before CT1 \& after CT3 before CT1 after CT3

Figure 6: Showing before and after changes in SGOT in avar sarata \& pravar sarata.

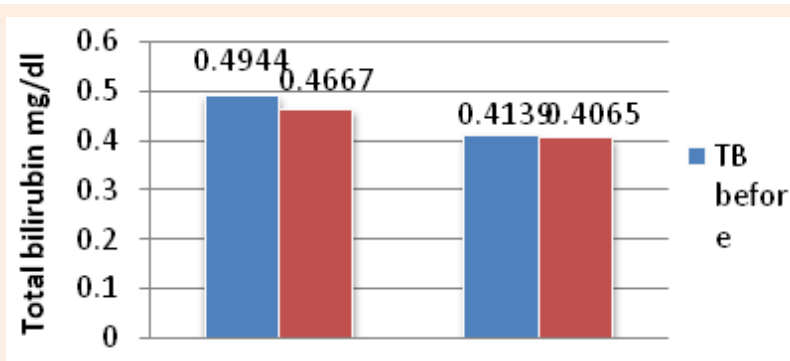

Avar sarata TB Pravar sarata TB before CT1 \& after before CT1 after CT3 CT3

Figure 7: Showing before and after changes in Total bilirubin (TB) in avar sarata \& pravar sarata.

Dashavidhaatur pariksha was explained by Acharya Charaka to examine a patient in respect to determine strength and the intensity of the diseased before giving any treatment. Therefore, physician should aim to improve quality of life of patient by means of proper choice of treatment, selection of proper drugs, and special care to be taken in case of avar satva sarata patient so as to improve immunity of asara and madhya sara dhatu with proper food and medicines and maintain uttam sarata of particular dhatu with proper counseling.

\section{Conclusion}

Pravar satva sara female of breast cancer receiving chemotherapy shows good response to treatment with minimal changes in their blood indices while Avar satva female are more susceptible for early side effects. Therefore, psychological and somatic disorders are more cause of disturbance in their integrity.

\section{References}

1. Sharma PV (1981) Agnivesha, Charak, Dridhabala, Charaksamhita, Sutra Sthana, Dirghagivitiya Adhaya. ( $1^{\text {st }}$ edn), In: $1 / 42$, Chaukhambha Orientalia, Varanasi, India.

2. Sharma PV (1981) Agnivesha, Charak, Dridhabala, Charaksamhita, Sutra Sthana, Nvegandharaniya adhaya. (1 ${ }^{\text {st }}$ edn), In: 7/51, Chaukhambha Orientalia, Varanasi, India.

3. Sharma PV (1981) Agnivesha, Charak, Dridhabala, Charaksamhita, Viman Sthana,Rogbhisikgitiya Viman. ( $1^{\text {st }}$ edn), In: 8/110. Chaukhambha Orientalia, Varanasi, India, pp.379.

4. Ferlay J, Shin HR. Bray F, Forman D, Mathers C, et al. (2010) Estimates of worldwide burden of cancer in 2008. Int J Cancer 127(12): 2893-9217.

5. Thomas AB, Kelly KH, Gary JW, Aysegul AS, Gabriel NH (2003) Neoadjuvant Chemotherapy For Breast Carcinoma Multidisciplinary Considerations of Benefits and Risks. Cancer 98(6): 1150-1160.

6. Sharma PV (1981) Agnivesha, Charak, Dridhabala, Charaksamhita, Sutra Sthana, Dirghagivitiya adhaya. ( $1^{\text {st }}$ edn), In: $1 / 55$. Chaukhambha Orientalia, Varanasi, India.

7. Zhao R, Qiao Q, Yue Y, Yi SB, Chen L, et al. (2003) The psychological impact of mastectomy on women with breast cancer. Zhonghua Zheng Xing Wai Ke Za Zhi 19(4): 294-296.

8. Beaver K, Williamson S, Briggs J (2016) Exploring patient experiences of neo-adjuvant chemotherapy for breast cancer. Eur J Oncol Nurs 20: 77-86.

9. Ichikawa H, Nakamura Y, Kashiwada Y, Aggarwal BB (2007) Anticancer drugs designed by Mother Nature: ancient drugs but modern targets. Curr Pharm Des 13(33): 3400-3416.

10. Sharma PV (1981) Agnivesha, Charak, Dridhabala, Charaksamhita, Viman Sthana,Rogbhisikgitiya Viman. ( $1^{\text {st }}$ edn), In: 8/102. Chaukhambha Orientalia, Varanasi, India, p. 378.

11. Srikantha Murthy (2011) Sushruta Samhita, Sharir Sthana, Garbhavyakaran Sharir Adhyaya, 4/81-87. Chaukhambha Orientalia, Varanasi, India, p. 74

12. Anand P, Kunnumakkara AB, Sundaram C, Harikumar KB, Tharakan ST, et al. (2008) Cancer is Preventable Disease that Requires Major Lifestyle Changes. Pharm Res 25(9): 2097-2116.

13. Sharma PV (1981) Agnivesha, Charak, Dridhabala, Charaksamhita, Sutra Sthana, Tistraishniya adhay. (1 ${ }^{\text {st }}$ edn), In: $11 / 54$. Chaukhambha Orientalia, Varanasi, India. 
14. Srikantha Murthy (2011) Sushruta Samhita, Sutra Sthana, Shonitvarniya Adhyaya. 14/21. ( $1^{\text {st }}$ edn), Chaukhambha Orientalia, Varanasi, India, p. 91
15. Sharma PV (1981) Agnivesha, Charak, Dridhabala, Charaksamhita, Sutra Sthana, Dirghagivitiya adhaya. ( $1^{\text {st }}$ edn), In: $1 / 57$ Chaukhambha Orientalia, Varanasi, India. 